\title{
A Survey on English Learning Motivation of Students in Qingdao Agricultural University
}

\author{
Guirong Pan \\ Foreign Languages School, Qingdao Agricultural University, Qingdao, China \\ Email: willa@qau.edu.cn \\ Yiming Zang \\ Haidu College, Qingdao Agricultural University, China \\ Dan $\mathrm{Wu}$ \\ Foreign Languages School, Qingdao Agricultural University, Qingdao, China.
}

\begin{abstract}
A survey from students of both Advanced and Ordinary English classes in Qingdao Agricultural University shows that most of the students are motivated by both intrinsic and extrinsic motivations. However, intrinsic motivation is more important than extrinsic motivation in contributing to English learning. There is no difference in anxiety between students in Advanced English class and in Ordinary English class and the attitude of students in Advanced English class is more proper than that of students in Ordinary English class. Therefore, they are more active in English learning than the students in Ordinary English Class are. The higher autonomous learning ability they have, the better the achievement they get.
\end{abstract}

Index Terms - motivation, intrinsic motivation, extrinsic motivation, English learning

\section{INTRODUCTION}

Motivation is one of the most important factors affecting foreign language learning. Spolsky (1989) said "the more motivation a learner has, the more time he or she will spend learning an aspect of a second language." In one of the earliest statements on motivation in second language learning, Gardner defines motivation as referring to a combination of effort plus desire to achieve the goal of learning the language plus favorable attitude towards learning the language.(Gardner 1985)

Williams and Burden mentioned that sometimes people do something because the act of doing it is enjoyable in itself. At other times, people are engaged in an activity not because they are particularly interested in the activity itself, but because performing it will help them to obtain something that they want. Therefore, Csikszentmihalyi and Nakamura (1989) provide a clear definition of these concepts. Very simply, when the only reason for performing an act is to gain something outside the activity itself, such as passing an exam, or obtaining financial rewards, the motivation is likely to be extrinsic. When the experience of doing something generates interest and enjoyment, and the reason for performing the activity lies within the activity itself, then the motivation is likely to be intrinsic.

Intrinsically motivated activities are ones for which there is no apparent reward except the activities itself. People seem to engage in the activities for their own sake and not because they lead to an extrinsic reward. Intrinsically motivated behaviors are aimed at bringing about internally rewarding consequences, namely feeling of competence and self-determination.

Extrinsically motivated behaviors, on the other hand are carried out in anticipation of a reward from outside and beyond the self. Typical extrinsic rewards are money, prizes, grades, and even certain types of positive feedback. Behaviors initiated solely to avoid punishment are also extrinsically motivated, even though numerous intrinsic benefits can ultimately accrue to those who, instead, view punishment avoidance as a challenge that can build their sense of competence and self-determination The intrinsic motivation is sometimes thought to relate to long-term success. Extrinsic motivation is thought more related to short-term success.

Many researches have different opinions about which motivation is more powerful. Maslow stated in 1970 that intrinsic motivation is obviously more powerful than extrinsic motivation. He believes that when one's basic life, safely and social needs are secured; people make efforts to obtain self-esteem and sense of accomplishment, mindless of what rewards are.

Some researchers, most notably Susan Harter (1981), view "intrinsic" and "extrinsic" as the opposite ends of a continuum. From Harter's studies, it is far more realistic to suggest that one form of motivation influences another, or indeed to see all the factors interacting to affect each other.

In order to know how motivations influence students' achievement, and which motivation can contribute more to help students' learning, the author investigates the students in Advanced English class and students in Ordinary English 
class in Qingdao Agricultural University. The following are the survey and the results.

\section{MEthodOLOGY}

\section{A. Subjects}

In Qingdao Agricultural University, non-English major students are divided into two levels of English Classes---Advanced English Class and Ordinary English Class according to their English level. The achievement of students in Advanced English Class is higher than that of students in the Ordinary English Class. In order to find the reasons, an investigation was made between students from both Advanced English class and Ordinary English class. The survey was conducted on $24^{\text {th }}$ September 2007. The participants are 50 students including 25 students in Advanced English Class and 25 students in Ordinary English Class.

\section{B. Questionnaire}

The English Learning Motivation Questionnaire contains 25 statements, which need to be answered "Yes" or "No". The questionnaire is based on the English Learning Motivation Questionnaire written by Gaoyan. The purpose of the questionnaire tries to answer the following questions:

1. What type of English learning motivation do the non-English major students have in Qingdao agricultural university?

2. Is there a relation between the students' learning motivation type and their learning achievement?

3. Is there any relevance between the students' learning motivation type and their learning attitude?

A Food Science student helped me to distribute the questionnaire. He gave students in Advanced English class 25 papers and gave students in Ordinary English class 25 papers.

The participants were convinced that there were no right or wrong answers, and their responses had nothing to do with their English achievements. Furthermore, their responses would be handled without name.

These questions are divided into two parts. The first part is designed to investigate what type of English learning motivation. The second part is used to investigate the present situation of the students' English learning motivation from three aspects: the students' learning motivation, autonomous learning ability, learning anxiety and attitude.

\section{RESULTS AND DISCUSSION}

\section{A. Extrinsic Motivation}

TABLE1

STATEMENT 1-5

\begin{tabular}{|c|c|c|}
\hline Statement & $\begin{array}{c}\text { Advanced English } \\
\text { Class }\end{array}$ & $\begin{array}{c}\text { Ordinary English } \\
\text { Class }\end{array}$ \\
\hline 1. I learn English in order to pass various kinds of English tests. & $12(48 \%)$ & $15(60 \%)$ \\
\hline 2. I learn English in order to get the diploma. & $9(36 \%)$ & $12(48 \%)$ \\
\hline 3. I learn English in order to have the further two-year's study in \\
universities. & $4(16 \%)$ & $5(20 \%)$ \\
\hline 4. I learn English in order to go abroad. & $1(4 \%)$ & $19(76 \%)$ \\
\hline 5. I learn English in order to find a good job. & $23(92 \%)$ & $14 \%)$ \\
\hline
\end{tabular}

Table 1 is to investigate the students' extrinsic motivation. In general, it shows that the students in Ordinary English class say more "yes" than the students in Advanced English class do. Compared to students in Advanced English class, there are more students motivated by extrinsic motivation in Ordinary English class.

As for statement 1.48\% students of Advanced English class and 60\% students of Ordinary English class say 'yes', it shows that the purpose of more than half of students in Ordinary English class is to pass various kinds of English tests.

As for statement 2.36\% students of Advanced English class and 48\% students of Ordinary English class say "yes". It shows that less than half of the students have certificate motivation. They learn English not only for the diploma but also for the more practical purpose, such as find a good salary job.

Statement 3 indicates that most students both in Advanced English class and in Ordinary English class are not planning to take part in English-major postgraduate examination.

As for statement 4.4\% students of Advanced English class and 20\% students of Ordinary English class say "yes". This indicates that these students are very practical. In fact, not everyone can afford to go abroad. Going abroad needs a lot of money. It is a little difficult for most of the students.

As for statement 5, most students in Advanced English class and Ordinary English class say "yes", even though the Advanced English class students' percentage is a little higher than that of the Ordinary English class. The reasons may be analyzed as follows: with the reform and opening policy to foreign countries, our country has more frequent contract with foreign countries and the foreign company can supply us with more working post. So the foreign language talents are demanded highly. Besides, good salary and welfare stimulate students to learn English, so students are eager to learn 
English well in order to find well-paid jobs.

\section{B. Intrinsic Motivation}

TABLE 2

STATEMENT 6-10

\begin{tabular}{|c|c|c|}
\hline Statement & $\begin{array}{l}\text { Advanced English } \\
\text { Class }\end{array}$ & $\begin{array}{l}\text { Ordinary English } \\
\text { Class }\end{array}$ \\
\hline 6. I learn English because I like English. & $11(44 \%)$ & $9(36 \%)$ \\
\hline $\begin{array}{l}\text { 7. I learn English because I am interested in the culture of the } \\
\text { English speaking countries. }\end{array}$ & $8(32 \%)$ & $7(28 \%)$ \\
\hline $\begin{array}{l}\text { 8. I learn English because English is a world language, and I can } \\
\text { know the world better. }\end{array}$ & $18(72 \%)$ & $17(68 \%)$ \\
\hline 9. I learn English because I like English songs and films. & $11(44 \%)$ & $10(40 \%)$ \\
\hline $\begin{array}{l}\text { 10. I learn English because I like the lifestyle of the } \\
\text { English-speaking people. }\end{array}$ & $3(12 \%)$ & $3(12 \%)$ \\
\hline
\end{tabular}

Statement 6-10 is to investigate the intrinsic motivation. From the table Statement 6-10, it can be seen that there are more students motivated by intrinsic motivation compared to students in Ordinary English class. But less than half of the students in both Advanced and Ordinary English classes are motivated by intrinsic motivation, except for Statement 8. The reason may be analyzed as following "Firstly, in China, English is not used as a medium of daily communication. The student cannot have enough experience of communication with the native speakers or living in the English-speaking countries. Therefore, his motivation is not as high as the English majors who must learn to communicate fluently in the target language. Secondly, the non-English majors have their own major courses to learn. They can not spend all their time and energy in learning English as English majors who devote most knowledge concerning to it." However, with the globalization, people need to communicate in order to know each other better. English is considered as an international language, as a student in the $21^{\text {st }}$ century, almost every student have this consciousness. Therefore, we can find that $72 \%$ students in Advanced English class and 68\% students in Ordinary English class say "yes" to Statement 8. They feel English is a world language, if they learn English well, they can know the world better.

From Table 1 and 2, it can be seen that most of the students are motivated both by intrinsic and extrinsic motivation. However, compared to students in Ordinary English class, there are more students in Advanced English class motivated by intrinsic motivation. While just as above mentioned, the achievement of students in Advanced English Class is higher than that of students in the Ordinary English Class. Therefore, it can be deduced that intrinsic motivation is more important in contributing to English learning compared to extrinsic motivation.

From the results of the survey, the author can conclude that types of motivation make difference in the students' achievements. Compared to extrinsic motivation, intrinsic motivation is more powerful.

\section{Autonomous Learning Ability}

TABLE 3

STATEMENT 11-15

\begin{tabular}{|l|l|l|}
\hline Statement & $\begin{array}{l}\text { Advanced English } \\
\text { Class }\end{array}$ & $\begin{array}{l}\text { Ordinary English } \\
\text { Class }\end{array}$ \\
\hline 11. In English classes, I feel my time passes very slowly. & $11(44 \%)$ & $15(60 \%)$ \\
\hline 12. After class, I seldom learn English voluntarily & $12(48 \%)$ & $14(56 \%)$ \\
\hline 13. when I learn I am not in the mood & $5(20 \%)$ & $13(52 \%)$ \\
\hline $\begin{array}{l}\text { 14. I dislike spending more time learning English except finishing } \\
\text { teachers' assignment. }\end{array}$ & $5(20 \%)$ & $12(48 \%)$ \\
\hline 15. I often left it go when meeting troubles in learning English & $3(12 \%)$ & $10(40 \%)$ \\
\hline
\end{tabular}

Statements 11-15 are to investigate the students' autonomous learning ability. If the students' autonomous learning ability is too low, it refers to their learning motivation is weak.

Table 3 shows that students' autonomous learning ability in Ordinary English class is low and his English learning motivation is too weak. However, most students in Advanced English class have high autonomous learning ability. It indicates that autonomous learning ability of the students in Advanced English class is higher than that of the students in Ordinary English class. It means that the motivation of students in Advanced English class is strong than that of students in Ordinary English class. It indicates that most students in Ordinary English class have some problems in learning autonomy. These students have trouble in taking charge of their own learning. It shows that their English learning motivation is not clear and proper. Their learning motivation is weak. If they adjust their English learning motivation properly, things will become better.

From the results of the survey, it can be concluded that the autonomous learning ability of students in Advanced English class is higher than that of students in Ordinary English class. It indicates that motivation of students in Advanced English class is stronger than that of students in Ordinary English class. 
TABLE 4.

STATEMENT 16-20

\begin{tabular}{|c|c|c|}
\hline Statement & $\begin{array}{c}\text { STATEMENT 16-20 } \\
\text { Class }\end{array}$ & $\begin{array}{c}\text { Ordinary English } \\
\text { class }\end{array}$ \\
\hline $\begin{array}{c}\text { 16. I'm always anxious about my poor English } \\
20(80 \%)\end{array}$ & $20(80 \%)$ \\
\hline $\begin{array}{c}\text { 17. I want to be the top student in English learning in class. } \\
\text { assignment. }\end{array}$ & $18(72 \%)$ & $12(48 \%)$ \\
\hline $\begin{array}{c}\text { 18. In English learning, I'm not just satisfied with finishing } \\
\text { 19. In order to learn English well, I give up many favorite activities } \\
\text { like doing sports, listening music etc. }\end{array}$ & $3(60 \%)$ & $4(16 \%)$ \\
\hline 20. I want to beat others in English contests. & $3(12 \%)$ & $14(56 \%)$ \\
\hline
\end{tabular}

Statements 16-20 are to investigate the students' anxiety in English learning. If the students' anxiety in English learning is too high, it means their learning motivation is too strong and their motivational intensity is high.

As for the statement 16, $80 \%$ of students both in Advanced English class and in Ordinary English class is anxious about their poor English. The reason may be analyzed that non-English major students are required to pass CET-4, if they failure, they cannot get the diploma in Qingdao Agricultural University.

$72 \%$ of students in Advanced English class and 84\% of students in Ordinary English class say "yes" to Statement 17. It indicates that most students are emulative. They desire to learn English well. But the more emulative the students have, the more anxious the students have.

In general, from the statement 16-20, there is no difference in students' anxiety in English learning for the students in Advanced English class and Ordinary English class. The conclusion is that most students in Advanced English class and Ordinary English class have high anxiety.

The relationship between anxiety and language learning is complicated. Until recently, research in the area of anxiety as it relates to second or foreign language learning has been inconclusive. However, one thing is certain that lower anxiety levels are related to successful second language learning. It seems that a student's evident manifestations of anxiety in the foreign language classroom will certainly impair the smooth performance of freer, learner-centered teaching of the target language, and simultaneously discourage the teacher to try new methods. Often there is enough evidence to show whether the students are anxious or not. If they are found to have such physical and psychological changes as fewer imitations of conversations, less participation in conversations or drill training, few instances of silence breakers, shorter speaking periods in front of an audience, distortion of sounds, and 'freezing up' when performing in communicative practice, they can be said to be experiencing pressure of anxiety. Therefore, teachers should induce in learners a relaxed and comfortable state of mind in order to maximize language learning.

From the results of the survey, learning anxiety of students both in Advanced English class and in Ordinary English class is high. However, high anxiety may affect their English learning.

\section{E. Learning Attitude}

TABLE 5

STATEMENT 21-25

\begin{tabular}{|c|c|c|}
\hline Statement & $\begin{array}{c}\text { Advanced English } \\
\text { Class }\end{array}$ & $\begin{array}{c}\begin{array}{c}\text { Ordinary English } \\
\text { class }\end{array} \\
\end{array}$ \\
\hline $\begin{array}{l}\text { 21.Although being stressed, I'm still confident in my own English } \\
\text { learning }\end{array}$ & $22(88 \%)$ & $14(56 \%)$ \\
\hline 22. I'd rather like to finish all tasks in English learning. & $17(68 \%)$ & $13(52 \%)$ \\
\hline $\begin{array}{l}\text { 23. In class, I often cooperate well with the teacher in class and after } \\
\text { class. I have certain learning autonomy. }\end{array}$ & $5(20 \%)$ & $8(32 \%)$ \\
\hline 24. I'm really interested in learning English. & $15(60 \%)$ & $11(44 \%)$ \\
\hline 25. I have a strong desire to speak with foreigner when meet them. & $11(44 \%)$ & $11(44 \%)$ \\
\hline
\end{tabular}

Statements 21-25 are to investigate the students' English learning attitude. If the students' English learning attitude is not proper, it indicates their learning motivation is troubled.

The answers to statement 21shows that students' confidence in Advanced English class is higher than that of the students in Ordinary English class is. Achievement can account for it. Achievements of students in Advanced English class are higher than that of students in Ordinary English class. Their higher achievements give their more confidence.

The answer to statement 22 indicates that the students in Advanced English class are more active than the students in Ordinary English class are. The students' efficiency in Advanced English class is higher.

As for the statement 23, less than half of students in both Advanced English class and Ordinary English class cooperate well with the teacher. Even though students' percentage in Advanced English class is lower than students' percentage in Ordinary English class.

As for the statement 24, more than half of students in Advanced English class are interested in learning English. However, less than half of students in Ordinary English class are interested in learning English. Their different motivation can account for it. 
Generally speaking, Table 5 shows that the attitude of students in Advanced English class is more proper than that of students in Ordinary English class. The reasons can be related to their motivation type. Before we know the reason, we should acknowledge the relations between attitude and motivation.

Attitude and motivation related directly and closely with each other, which in turn is directly responsible for the success or failure of L2 learning. Motivation depends on attitude, to some extent, and attitude should be viewed as the motivational support, which only has an indirect impact on L2 learning. The relation of attitude to motivation is dependent upon the type of motivation.

Table 2 shows that the students in Advanced English class are more intrinsic motivation than the students in Ordinary English class are. In addition, table 5 shows attitude of the students in Advanced English class is more proper than that of the students in Ordinary English class. An intrinsic motivation can form a more positive motivation.

Many studies have suggested that attitudes toward learning a language would relate to achievement in the language learning. A study conducted by Jordan among 231 students demonstrated that attitudes toward learning a language are more relevant to achievement than attitudes toward learning many other school subjects. Studies have also indicated that attitudes toward learning a foreign language are quite probably affected by the students' previous achievement in learning the language. For instance, in China, as all the college students have had some experience of learning a foreign language by the time they enter college, their earlier success would promote positive attitudes in their college studies, therefore, in most cases, students who learn the foreign language well are those who were more successful in the language course in the middle school. There is no difficulty to see it.

As we have mentioned above, the achievement of students in advanced English class is higher than that of students in ordinary English class. When the non-English major students in Qingdao Agricultural University entered college, they are divided into two levels of class according to their English achievements. So it is easy to understand that achievement of most students in advanced English class is good in senior school.

\section{CONCLUSION}

From the above analysis, the following is concluded:

(1) Compared to students in Ordinary English class, there are more students motivated by intrinsic motivation in Advanced English class. The achievement of students in Advanced English Class is higher than that of the students in Ordinary English Class. Logically, intrinsic motivation is more important than extrinsic motivation in contributing to English learning. Therefore, there is relationship between the motivation type and achievement.

(2) English achievement is concerned with autonomous learning ability. The higher autonomous learning ability is, the better the achievement is. The autonomous learning ability of students in Ordinary English is weak and their achievements are lower. So the autonomous learning ability of students in Ordinary English class needs to be enhanced.

(3) There is no difference in anxiety. Students both in Advanced English class and Ordinary English in Qingdao Agricultural University are full of anxiety.

(4) Generally speaking, the attitude of students in Advanced English class is more proper than that of students in Ordinary English class. Because of different motivation and relationship between motivation and attitude, intrinsic motivation presupposes a positive attitude towards the target language.

Based on the above theory, teachers are suggested to make the learners engaged in enhancing the students' intrinsic motivation, arousing the students' interest and curiosity, fostering learners' autonomy, building up a good teacher-student relationship.

Like all other studies, there are limitations in this study. The first one is the data collection. The number of the subjects is not big enough. The second problem is about the reliability of questionnaire. Some subjects might flatter the investigation in responding to the questionnaire or choose the opposite items on purpose. If permitted, the further research should investigate the more subjects representing the entire situation. The difference between students in Advanced English class and Ordinary English class need to be more apparent.

\section{REFERENCES}

[1] Atkinson, J.W. (1964). An Introduction to Motivation. Princeton . N.J.: Van Nostrand

[2] Brophy,J. (1987). Synthesis of Research on Strategies for Motivating Students to Learn. Educational Leadership,45(2),40-48.

[3] Csikszentmihalyi, M., \& Nakamura, J. (1989). The dynamics of intrinsic motivation: A study of adolescents. In R. Ames \& C. Ames (Eds.), Research on motivation in education: Goals and cognitions (pp.45-71). New York: Academic Press

[4] Gardner, R.C. (1985), Social Psychology and Second Language Learning: The role of attitudes and motivation, London: Edward Arnold

[5] Jane Weiss. (2004). Applied linguistic an Advanced Course. Shanghai: Shanghai Foreign Language Education Press

[6] Spolsky, B (1989). Conditions for Second Language Learners. Oxford: Oxford University Press

[7] Susan Harter (1981) A New Self-report Scale of Intrinsic Versus Extrinsic Orientation in the Classroom: Motivational and Informational Components, Development Psychology, 17, 300-312

[8] William M, BurdenR L. (2000). Psychology for Language Teachers. Cambridge University Press, Foreign Language Teaching and Research Press, People's Education Press.

[9] Wen qiufang.(2001). Applied Linguistics . Beijing: Foreign Language Teaching and Research Press. 
[10] Wang Lifei.(2000). A Survey of Modern Second Language Learning and Teaching. Shanghai: Shanghai Foreign Language Education Press.

[11] Williams, B. and R.L. Burden. (1997). Psychology for Language Teachers. Cambridge: Cambridge University Press.

Guirong Pan was born in Yantai, China in1956. She received her M.A. degree in linguistics from Yantai Teachers' College, China in 1977.

She is currently a professor in the Foreign Languages School, Qingdao Agricultural University, Qingdao, China. Her research interests include psycholinguistics and applied linguistics.

Prof. .Pan is a member of the Chinese Association of Foreign Language Teachers.

Yiming Zang was born in Laiyang, Shandong, China in 1981. He received his M.A. degree in literature from Qingdao Agricultural University, China in 2006.

He is currently a teacher in Haidu College, Qingdao Agricultural University, China.

Dan Wu was born in Heze Shandong, China in 1987. She is currently a senior student in Foreign Languages School, Qingdao Agricultural University, Qingdao, China. 